\title{
Extracellular polygalacturonases from Penicillium frequentans: separation and regulatory aspects
}

\author{
Valéria SiÉsSere, Maria José Vieira FonseCa and Suraia SaID* \\ Departamento de Ciéncias Farmacêuticas, Faculdade de Ciências Farmacêuticas de Ribeirão Preto, \\ Universidade de São Paulo, 14.049 Ribeirão Preto, São Paulo, Brazil
}

(Received 13 February 1992; revised 10 June 1992; accepted 17 June 1992)

\begin{abstract}
Extracellular polygalacturonase activities of Penicillium frequentans were induced by pectin and repressed, but not inactivated, by glucose. The absence of a carbohydrate source derepressed $50 \%$ of viscosity-diminishing activity and $36 \%$ of reducing-groups-releasing activity compared to production in the presence of pectin. High concentrations $(30 \mathrm{mM}$ and $50 \mathrm{mM})$ of D-galacturonic acid reduced only the viscosity-diminishing activity, and under these conditions the fungus grew poorly. Neither effect was observed if the mycelium had been previously induced by pectin. Polygalacturonase activities produced in the presence of pectin were separated by ion exchange chromatography. These enzymes eluted in six peaks, characterized as exopolygalacturonases I, II and III and endopolygalacturonases, I, II and III.
\end{abstract}

\section{Introduction}

Fungal pectinolytic complexes are generally constituted by deesterifying enzymes (pectin esterases) and depolymerizing enzymes (endopolygalacturonase, exopolygalacturonase, exopectate lyase, endopectate lyase and endopectin lyase) (Rombounts \& Pilnik, 1980). These enzymes have commercial interest for the food and textile industries, and are also involved in phytopathogenic processes. Funtal pectinase production depends on environmental conditions and the characteristics of the organism (Strzelczyk et al., 1987; Manachini et al., 1988). It has been asked how pectic substances which cannot permeate into the cytoplasm can induce the synthesis of pectinases. A likely explanation is that micro-organisms produce low constitutive levels of extracellular enzyme activities. These partially degrade pectic substances, releasing low-molecular-mass products which induce the pectinase synthesis (Leone \& Van den Heuvel, 1987). Aspergillus constitutively produces exo-pectinase when grown on glucose, sucrose, fructose, glycerol or galacturonic acid (Aguilar \& Huitron, 1990).

In this work we investigated some regulatory aspects of the production of polygalacturonase by Penicillium frequentans, and the biochemical heterogeneity of these enzymes.

* Author for correspondence. Tel. 16633 3066; fax 166330567.

Abbreviation: NaPP, polygalacturonic acid sodium salt.

\section{Methods}

Micro-organism. Penicillium frequentans was isolated from Brazilian soil samples (Said et al., 1991), and deposited in the collection of the Fundação Tropical de Tecnologia e Pesquisa 'André Tosello' (Campinas São Paulo, Brazil). The organism was maintained by weekly transfers on slants of PDA medium, incubated at $30^{\circ} \mathrm{C}$.

Enzyme production conditions. The culture medium contained $\left(\mathrm{g}^{-1}\right)$ : $\mathrm{KH}_{2} \mathrm{PO}_{4}, 2.0 ;\left(\mathrm{NH}_{4}\right)_{2} \mathrm{SO}_{4}, 1.0 ; \mathrm{MgSO}_{4} .7 \mathrm{H}_{2} \mathrm{O}, 1.0 ; \mathrm{Na}_{2} \mathrm{HPO}_{4} .2 \mathrm{H}_{2} \mathrm{O}$, 0.9 ; yeast extract (Difco), 1.0 ; supplemented with $0.5 \%$ pectin, or according to the experimental protocol. The initial medium $\mathrm{pH}$ was adjusted to $2 \cdot 5$. The medium was inoculated with $5 \times 10^{6}$ spores $\mathrm{ml}^{-1}$ and incubated with agitation ( 100 r.p.m.) at $30^{\circ} \mathrm{C}$. The mycelium was separated from the culture fluid by filtration and the culture filtrate was dialysed against $25 \mathrm{mM}$-Tris/acetate buffer (pH 6.5) containing $1 \mathrm{~mm}$ EDTA (buffer A).

Enzyme assays. Polygalacturonase activity was quantified by measuring the release of reducing sugar groups, by the dinitrosalicylic acid method (Miller, 1959) at pH 4.8 and $50{ }^{\circ} \mathrm{C}$ using $1.0 \%(\mathrm{w} / \mathrm{v})$ polygalacturonic acid sodium salt (NaPP) in $25 \mathrm{~mm}$-sodium acetate buffer (buffer B). One activity unit was defined as the amount of enzyme which released $1 \mu \mathrm{mol}$ of reducing sugar groups per min, using D-galacturonic acid as standard. Polygalacturonase activity was also assayed by changes in viscosity. Viscosity-diminishing activity was determined by measuring the decrease in relative viscosity of a $0.5 \%$ $(w / v)$ solution of pectin in buffer $\mathrm{B}$, at $50^{\circ} \mathrm{C}$ using a Ostwald viscometer with a water flow time of $23 \mathrm{~s}$, calculated according to Mill \& Tuttobello (1961). One relative viscometric unit was defined as the amount of enzyme which reduced the initial viscosity of pectin solution by $50 \%$ in $1 \mathrm{~min}$ of reaction. Pectin esterase activity was assayed with a $1 \%(w / v)$ pectin solution in buffer $A$ as substrate, by continuous titrimetric determination of the carboxyl groups liberated from the methylester bonds after $2 \mathrm{~h}$ incubation at $50^{\circ} \mathrm{C}$. One unit was the amount of enzyme which released one microequivalent of carboxyl 

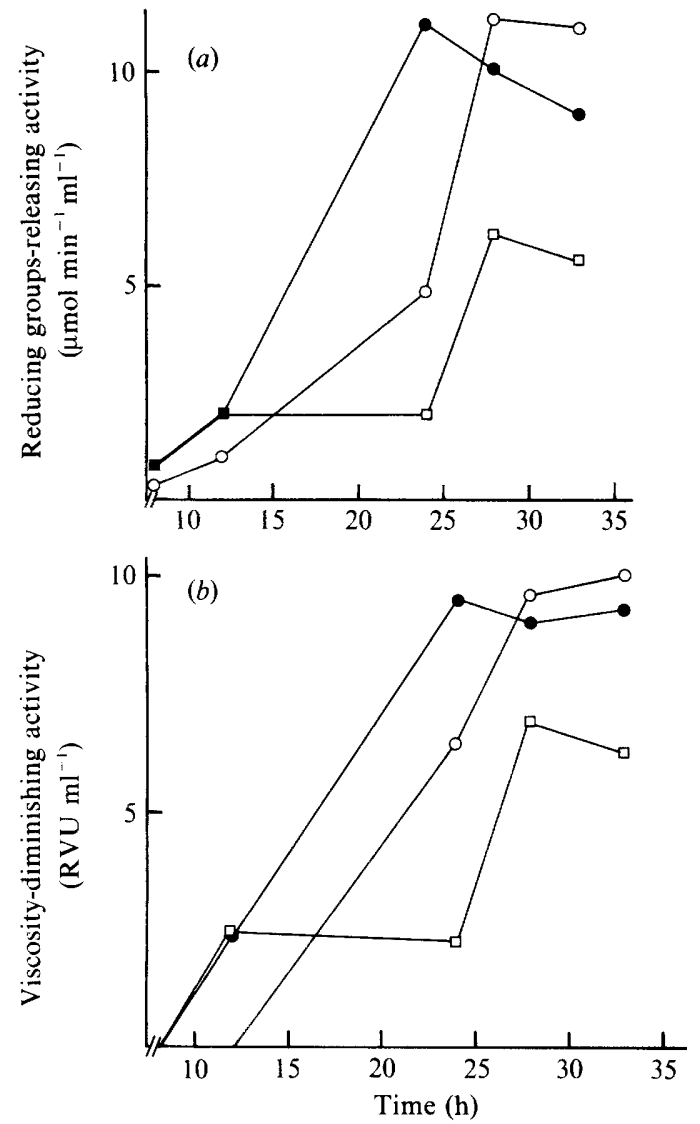

Fig. 1. Effect of glucose on the production of polygalacturonase by Penicillium frequentans, using $0.5 \%(\mathrm{w} / \mathrm{v})$ pectin as inducer $(\odot)$ and with addition of $30 \mathrm{~mm}$-glucose at zero time $(O)$ or after $12 \mathrm{~h}$ incubation $(\square)$. (a) Reducing-groups-releasing activity; (b) viscositydiminishing activity.

groups per min under the above conditions. Transeliminase activity was assayed by measuring at $50^{\circ} \mathrm{C}$ the increase in $A_{235}$ of the unsaturated products of degradation of $1 \%(\mathrm{w} / \mathrm{v})$ pectin or NaPP in

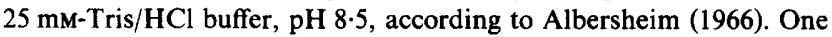
activity unit was defined as the amount of enzyme which released one $\mu \mathrm{mol}$ of unsaturated product per minute at $50{ }^{\circ} \mathrm{C}$. Protein was determined by the Lowry method using bovine serum albumin (Sigma) as standard or by measuring $A_{280}$. For dry weight determinations, the mycelium was rinsed and dried at $70^{\circ} \mathrm{C}$ until constant weight was attained.

Separation of pectic enzymes. The enzyme activities in dialysed culture filtrates were separated by two steps of column chromatography. Samples $(50 \mathrm{ml})$ of the crude filtrate were initially applied to a DEAE-Sephacel column $(1.6 \times 25 \mathrm{~cm})$ equilibrated with buffer $A$ and eluted by stepwise $(20,40,150$ and $300 \mathrm{~mm})$ increases in $\mathrm{NaCl}$ concentration in the same buffer. Fractions $(5.5 \mathrm{ml})$ were collected at a flow rate of $48 \mathrm{ml} \mathrm{h}^{-1}$, and the enzyme activities were determined. The protein not adsorbed on to the DEAE-Sephacel column (Pool I) was dialysed against $25 \mathrm{~mm}$-sodium acetate buffer $\mathrm{pH} 5 \cdot 0$, containing 1 mM-EDTA (buffer B) and was applied to a CM-Cellulose column $(1.6 \times 25 \mathrm{~cm})$ equilibrated with the same buffer. The protein was eluted by increasing $\mathrm{NaCl}$ concentrations ( 50 and $150 \mathrm{~mm}$ ) in buffer $\mathrm{B}$. Fractions $(5.5 \mathrm{ml})$ were collected at a flow rate of $33.5 \mathrm{ml} \mathrm{h}^{-1}$. The products of enzymic degradation of NaPP were examined by TLC (Fonseca et al., 1991).
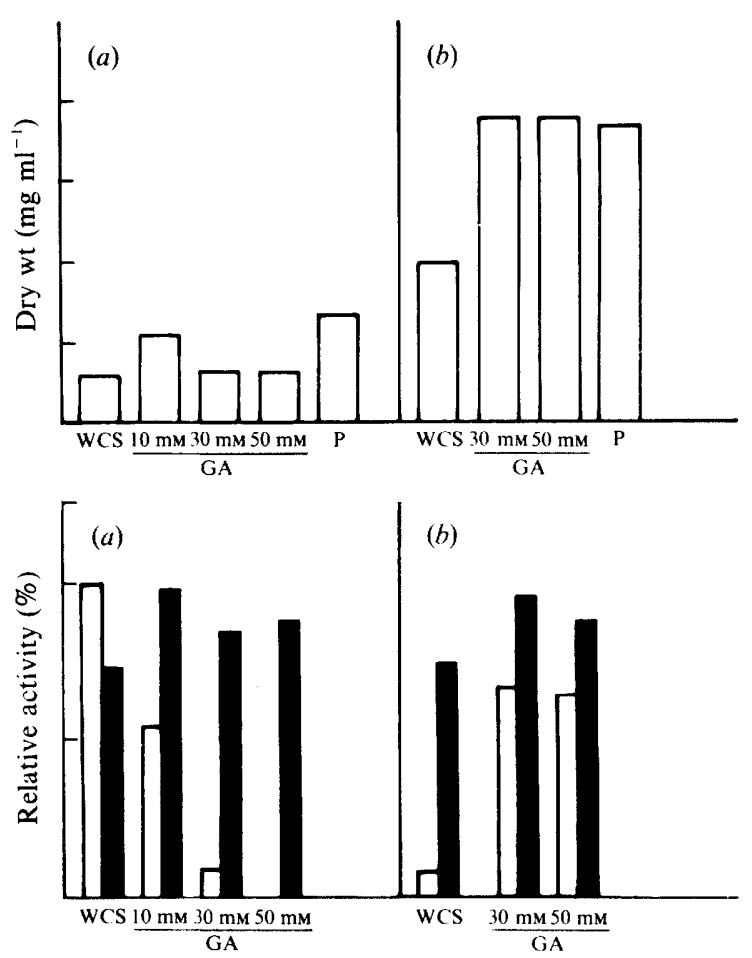

Fig. 2. Effect of D-galacturonic acid on growth (upper panels) and production of polygalacturonase (lower panels) by Penicillium frequentans. (a) Conidia $\left(5 \times 10^{6} \mathrm{ml}^{-1}\right)$ incubated for $17 \mathrm{~h}$ in a medium supplemented with $0.5 \%(\mathrm{w} / \mathrm{v})$ pectin $(\mathrm{P})$, or D-galacturonic acid (GA), or without carbohydrate source (WSC). (b) Mycelia obtained from $17 \mathrm{~h}$ cultures supplemented with $0.5 \%(\mathrm{w} / \mathrm{v})$ pectin, rinsed and transferred to fresh media containing $0.5 \%(\mathrm{w} / \mathrm{v})$ pectin, D-galacturonic acid or without carbohydrate source, and reincubated for a further 6 hours. Activities are expressed in percentages relative to those of a culture grown for $17 \mathrm{~h}(a)$ or $6 \mathrm{~h}(b)$ in the presence of $0.5 \%(\mathrm{w} / \mathrm{v})$ pectin. $\square$, Viscosity-diminishing activity; $\square$, reducing-groups-releasing activity.

Chemicals. Pectin, D-galacturonic acid, polygalacturonic acid sodium salt, CM-Cellulose and DEAE-Sephacel were from Sigma. All other chemicals were of the best quality available.

\section{Results and Discussion}

\section{Carbon source regulation of polygalacturonase production}

When Penicillium frequentans was grown for $12 \mathrm{~h}$ in a medium supplemented with $80 \mathrm{~mm}$-glucose, reducinggroup-releasing and viscosity-diminishing activity levels were very low, but fungal growth was good (not shown). When the cultures were first grown on $0.5 \%$ pectin for $12 \mathrm{~h}$, and $30 \mathrm{~mm}$-glucose was then added, the enzyme activities already present in the culture medium remained stable for about $12 \mathrm{~h}$, increasing again thereafter (Fig. 1). This result suggested that glucose repressed the synthesis but did not cause inactivation of these enzymes. If pectin and glucose were simultaneously present at the inoculum time, the fungus grew rapidly 

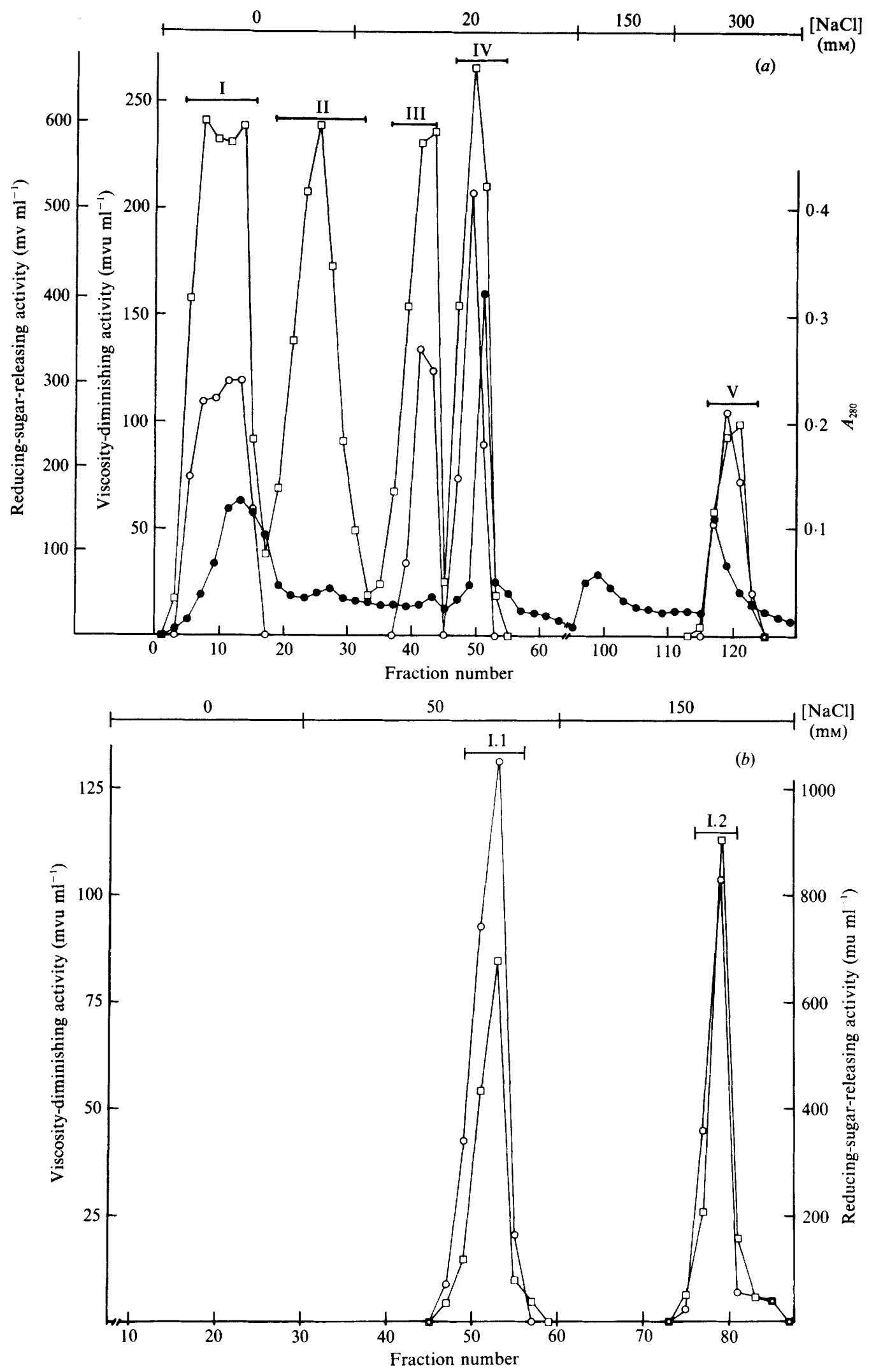

Fig. 3. Separation profiles on DEAE-Sephacel ( $a$ ) and CM-Cellulose $(b)$ of the extracellular polygalacturonases produced by Penicillium frequentans. Details are described in the text. The dialysed culture fluid was applied to a column $(1.5 \times 27 \mathrm{~cm})$. The columns were eluted by stepwise gradients of $\mathrm{NaCl}$ as indicated. Fractions of $4.8 \mathrm{ml}$ were collected and analysed for protein ( $)$ ), viscosity-diminishing activity $(O)$ and reducing-sugar-releasing activity $(\square)$. 
and viscosity-diminishing activity and reducing-groupsreleasing activity were very low for the first $12 \mathrm{~h}$. After this time the enzyme levels increased, probably as a consequence of glucose exhaustion. On the other hand, when the organism was incubated in a medium without carbohydrate source, after $17 \mathrm{~h}$ viscosity-diminishing and reducing-groups-releasing activities were $50 \%$ and $36 \%$, respectively, of those produced in cultures supplemented with $0.5 \%(\mathrm{v} / \mathrm{v})$ pectin, (Fig. $2 a$ ). These results suggested that the enzymes were partially derepressed in the absence of carbohydrate, in agreement with the results reported by Aguilar \& Huitron for Aspergillus (1990). The effect of D-galacturonic acid on the production of pectinases was also investigated (Fig. 2a). High concentrations of D-galacturonic acid negatively affected the level of viscosity-diminishing activity, but not that of the reducing-groups-releasing activity, which was the same as that of a culture incubated in a medium without a carbohydrate source. Under these conditions fungal growth was poor. The different effects of galacturonic acid on viscosity-diminishing activity and reducinggroups-releasing activity was also reported by Aguilar \& Huitron for Aspergillus sp. (1987). On the other hand, Leone \& Van der Heuvel (1987) reported that the number of pectinases produced by Botrytis cinerea was influenced by the type and concentration of the substrate and consisted of polygalacturonase and pectinesterase isoenzymes. Our results suggested that a high concentration of galacturonic acid added at the start of the culture repressed only the synthesis of viscosity-diminishing activity, probably because polygalacturonase activity produced by Penicillium frequentans consisted of various enzymes whose synthesis was independently controlled. When a culture previously grown for $17 \mathrm{~h}$ in a medium supplemented with $0.5 \%$ pectin was transferred to a fresh medium containing D-galacturonic acid at various concentrations, the mycelium was able to grow further and to secrete pectinolytic enzymes after $6 \mathrm{~h}$ (Fig. $2 b$ ). These results suggest that induction by pectin may be a requirement for induction of D-galacturonic acid metabolism, and that this substance is perhaps not the only, or the best, inducer of the pectinolytic system in Penicillium frequentans.

\section{Separation of polygalacturonase activities}

A crude enzyme preparation was applied to a DEAESephacel column and five peaks containing pectinolytic activities were resolved (Fig. $3 a$ ). Peak I was eluted with the equilibrating buffer. Elution of the column with a $\mathrm{NaCl}$ stepwise gradient yielded four other peaks containing pectinolytic activities. Peaks I, III, IV and V contained reducing-groups-releasing and viscosity-diminishing acitivities. The enzyme present in peak II showed predominantly reducing groups-releasing activity; but some viscosity-diminishing activity could be detected after long periods of incubation $(1-5 \mathrm{~h})$. The recovery of reducing-groups-releasing and viscositydiminishing activities initially present in the culture filtrate was $52.7 \%$ and $91.7 \%$, respectively. The pooled fractions of peak I were dialysed against buffer B and rechromatographed on a CM-cellulose column (Fig. $3 b$ ). The stepwise gradient elution of the column with $\mathrm{NaCl}$ yielded two peaks (I.1 and I.2) containing reducinggroups-releasing and viscosity-diminishing activities, with a yield of $99.4 \%$ and $64.6 \%$ respectively, as compared to that of peak I. Transeliminase activity was not detected, probably because the initial $\mathrm{pH}$ of the culture was 2.5 and, as we previously reported, at this $\mathrm{pH}$, lyase activity is not induced in Penicillium frequentans (Said et al., 1991). The endo- or exo-nature of the enzymes present in the resolved peaks was determined by comparing the release of reducing groups and the viscosity changes of a pectin solution as a function of time. The enzymes present in peaks I.1, I.2 and V hydrolysed $3.3 \%, 14 \%$ and $12.5 \%$ of glycosidic bonds of $\mathrm{NaPP}$, respectively, at the time when the viscosity of the reaction mixture was decreased by $50 \%$. These polygalacturonases appeared to be endopolygalacturonases, since they promoted a sharp drop in viscosity (half value at 10 to $15 \%$ hydrolysis) with only a slow increase of reducing end groups, (Rombouts \& Pilnik, 1980). The enzymes of peaks I.1, I.2 and V were named endo-PG I, II and III, respectively. The enzymes present in peaks II, III and IV hydrolysed $69 \%, 40 \%$ and $35 \%$ of glycosidic bonds, respectively, at the time when the viscosity of reaction mixture was decreased by $50 \%$, and thus these enzymes appeared to be exopolygalacturonases, and were named exo-PG I, II and III. These results were confirmed by examining the products of NaPP degradation by TLC, which showed that the hydrolysis by enzymes from peaks I.1, I.2 and V produced little or no D-galacturonic acid, while those of peaks II, III and IV produced high concentration of this sugar after $30 \mathrm{~min}$ reaction. When $1 \%(\mathrm{w} / \mathrm{v}) \mathrm{NaPP}$ was the substrate, reducing-groups-releasing activity in all peaks was higher than when $1 \%(\mathrm{w} / \mathrm{v})$ pectin was used as substrate, suggesting that NaPP was the preferred substrate of these enzymes and, since lyase activity was not detected under these environmental conditions, it can be concluded that these enzymes are polygalacturonases.

This work was supported by grants from Fundação de Amparo à Pesquisa do Estado de São Paulo (FAPESP) no. 89/2902-0 and Conselho de Desenvolvimento Científico e Tecnológico (CNPq). V.S. received a graduate (master) fellowship from Coordenadoria de Aperfeiçoamento de Pessoal de Ensino Superior (CAPES). S.S. is a Research Fellow of CNPq. This work is part of a thesis submitted by V.S. to the Department of Genetics of the School of Agronomy Luiz de 
Queiroz (University of São Paulo) in partial fulfilment of the requirements for the master degree.

We thank Dr Héctor Francisco Terenzi for valuable discussions and suggestions, Maria Angélica dos Santos Cunha Chellegatti and André Luiz Ignácio for technical assistance and Rita de Cássia Figueiró for preparation of the manuscript.

\section{References}

Aguilar, C. \& Huitron, C. (1987). Stimulation of the production of extracellular pectinolytic activities of Aspergillus sp. by galacturonic acid and glucose addition. Enzyme and Microbial Technology 9, 690-696.

Aguilar, C. \& Huitron, C. (1990). Constitutive exo-pectinase produced by Aspergillus sp. CH-Y-1043 on different carbon source. Biotechnology Letters 12, 655-660.

Albersheim, P. (1966). Pectin lyase from fungi. Methods in Enzymology, 8, 628-631.

Fonseca, M. J. V., SPadaro, A. C. C. \& SAID, S. (1991). Separation of the components of the pectolytic complex produced by Tubercularia vulgaris in solid state culture. Biotechnology Letters 13, 39-42.
LEONE, G. \& VAN DEN HeUVEL, J. (1987). Regulation by carbohydrates of the sequential 'in vitro' production of pectic enzymes by Botrytis cinerea. Canadian Journal of Botany 65, 2133-2141.

Manachini, P. L., Parini, C. \& Fortina, M. G. (1988). Pectic enzymes from Aureobasidium pullullans LV 10. Enzyme and Microbial Technology 10, 682-685.

Mill, P. J. \& TUTTOBELLO, R. (1961). The pectic enzymes of Aspergillus niger. II: Endopolygalacturonase. Biochemical Journal 79, 57-64.

MILLER, G. L. (1959). Use of dinitrosalicylic acid reagent for determination of reducing sugars. Analytical Biochemistry 31, 426-428.

Rombouts, F. M. \& PILNIK, W. (1980). Pectic enzymes. In Economic Microbiology, vol. 5, pp. 227-282. Edited by A. H. Rose. Academic Press: London.

SAID, S., FonseCa, M. J. V. \& Siéssere, V. (1991). Pectinase production by Penicillium frequentans. World Journal of Microbiology and Biotechnology 7, 607-608.

STRZELCZYK, E., DAkM, H. \& KowalsKi, S. (1987). The influence of pH and temperature on cellulolytic and pectolytic activity of Cylindrocarpon destructans (Zins) Scholt. Journal of Phytopathology 120, 97-103. 